DOI:

УДК 347.453 .1

Nataliia Maika,

Candidate of Juridical Sciences, Instructor

of the Department of Civil Law and

Process, Ternopil National Economic University

ORCID: http://orcid.org/0000-0002-5676-980X

Nataliia Butryn-Boka,

Candidate of Juridical Sciences Associate

Professor, Associate Professor of the

Department of Civil Law and Process, Ternopil

National Economic University

ORCID: http://orcid.org/0000-0003-3684-7177

\title{
MAIN PROVISIONS OF LEASE AGREEMENT: DRAFT COMMON FRAME OF REFERENCE AND CIVIL CODE OF UKRAINE
}

In the context of the adaptation legislation to the European standards, the article presents a comparative analysis of the norms of contractual lease obligations on the basis of acts of EU legislation and national code. Determine the main definitions, content and form of the lease agreement in both legislative acts.

The aim of the research is to make a comparative analysis of the norms of European legislation and national legislation based on the CCU and DCFR.

Based on the analysis of the application of definitions, we can conclude that the DCFR-generalized use of property under one definition, and in our opinion, it is more acceptable for ease use in practice. We believe that the legislation should apply the unified terminology of the most important institutions.

Keywords: lease agreement; hire; the subject of the lease; the term of the lease; the form of the lease; State registration.

\section{Bibl.: 5.}

Майка Н., Бутрын-Бока Н.

Основные положения о договоре аренды: DCFR и ГК Украины

В контексте адаптации законодательства к европейским стандартам, в статье освещень сравнительный анализ норм договорных арендных обязательств на основании актов законодательства СС и национального кодекса. Определень основные дефиниции, содержание и форму договора аренды в обеих законодательных актах.

Целью исследования является сравнительный анализ норм европейского законодательства и национального законодательства на основе ГК Украины и DCFR.

Сделаны выводы, что в DCFR - обобщенно пользования имущзеством под одной дефиницией, что является более приемлемым для удобства использования в практической деятельности.

Ключевые слова: договор аренды; наем; предмет договора арендығ; срок договора арендыз; форма договора аренды; государственная регистрация.

\section{Майка Н., Бутрин-Бока Н.}

Основні положення про договір оренди: DCFR та ЦК Украйни

У контексті адаптації законодавства до європейських стандартів відображено порівняльний аналіз норм договірних орендних зобов'язань на основі актів законодавства ЄС та національного кодексу. Визначено основні дефініиії, зміст та форму договору оренди в обох законодавчих актах.

Метою дослідження є порівняльний аналіз норм європейського законодавства та національного законодавства на основі ЦК Украӥни та DCFR.

Зроблено висновки, щуо в DCFR - узагальнено користування майном під однією дефінічією, щуо є більщ прийнятним для зручності використання у практичній діяльності. Позитивним надбанням обох нормативноправових актів $\epsilon$, те, щзо вони сформовані за структурою від загальних положень до спеціальних інститутів. ЦК України перевантажений нормами, щчодо окремих типів оренди. Вважаємо, щчо істотні умови договору оренди, перераховувати в самому ичивільному акті - необхідності немає, изі норми мають міститися для 
зручності в спечіальних актах. DCFR визначає, щзо предметом договору є майно, а так не акцентує увагу на різних предметах довогору оренди, на відміну від національного кодексу. Можемо відмітити, щзо ие найбільш прийнятне та зручне правозастосування, щзо виключає плутанину. Адже майно, як значення, об'єднує в собі окрему річ, сукупність речей, а також майнові права та обов'язки, щзо $і$ відповідає $і$ національному правопорядку. Щодо такої істотної умови договору оренди, як строк, то украӥнське законодавство містить обмеження щзодо мінімального та максимального строку, щуо непритаманне для європейського акту. Так, як у світі простежується тенденція до зменшення залежності орендаря від орендодавия, Украйна має перейняти позитивний досвід.

Ключові слова: договір оренди; найм; предмет договору оренди; строк договору оренди; форма договору оренди; державна реєстрачія.

Formulation of the problem. The lease agreement is one of the most popular contract constructions applied for transferring property for use. This agreement is applicable in both business and household sectors.

Over $80 \%$ of American businesses lease at least one of their equipment acquisitions, and nearly $90 \%$ say they would choose to lease again [4].

One of the reasons for the demand for rent (lease) is its flexibility in comparison to rigid ownership, which creates additional opportunities for the organization of production and management of its resources. In this case, the rent (lease) agreement creates the most favorable conditions for both business development and for meeting the household needs of the population, satisfying the interests of both the owners of the capital in obtaining certain goods, and persons who do not own such capital, but need to use its useful properties.

This type of contract regulates relationships related to the temporary use of property without the acquisition of property. The focus of the contract on the more rational use of things makes the scope of its application wide. Receiving temporary use of the property, the person does not spend money on its acquisition of the property.

The second party, who does not currently need the property he owns, rents it out, not only is exempt from the running costs of maintaining it, but also receives a rent, has the opportunity to earn income.

Analysis shows that for the landowner the value of the bundle of property rights to land is determined by the type of lease contract. Landowners prefer lease contracts with as little regulation as possible [5]. Leasing relationship becomes more and more important. It is becoming more and more prominent, derived from the rental housing contradiction, the housing lease between the lessee in disadvantage, in order to maintain the harmony of people's livelihood and social stability, our country law expressly stipulated, give the lessee legal protection [3].

Therefore, the issue of examining the regulations of the law in comparison to the Civil Code of Ukraine (CCU) [1] and the Draft Common Frame of Reference (DCFR) [2] is extremely relevant and interesting in the context of the harmonization of Ukrainian and European private law.

The aim of the research is to make a comparative analysis of the norms of European legislation and national legislation based on the CCU and DCFR.

Analysis of recent research and publications. The legal nature of the lease agreement was investigated by Chang-Yue Shen, Ling-Yun Zhang [3], M. Hamid [4], N.B.P. Polman [5], and others.

Main results of research. In DCFR we use definition «lease» is the legal relationship arising from a contract under which one party, the lessor, undertakes to provide the other party, the lessee, with a temporary right of use in exchange for rent. (IV.B.-1:101) [2] . A contract for the lease of goods is a contract under which one party, the lessor, undertakes to provide the other party, the lessee, with a temporary right of use of goods in exchange for rent. The rent may be in the form of money or other value.

Art. 759 of the CCU determines that due to the rent (lease) contract the landlord transfers or undertakes to transfer to the lessee the property for use for a fee for a definite period [1]. However, the Ukrainian legislator, due to the historical development of civil law in Ukraine and the use of legal terminology, gradually developed an understanding of «rent» and «hire» as identical concepts. In parallel, the term «lease» for the convenience of perceiving locatio-conductio rei novelists of the nineteenth century used as its subtypes, with two meanings: as lease of land and as lease of real estate.

Therefore, based on the analysis of the application of definitions, we can conclude that the DCFR generalized use of property under one definition, and in our opinion, it is more acceptable for ease use in practice. We believe that the legislation should apply the unified terminology of the most important institutions.

In our opinion, a positive feature of regulatory acts is that they are formed in a structure from general to special. CCU contains general provisions for the hiring of paragraph 1 of Chapter 58 , followed by the structure of the provisions specifically for contracts on the subject (paragraph 2-6 of Chapter 58, Chapters 59-60) [1]. DCFR: contains general lease provisions (Part B IV. B.) [2]. 
Цивільне право і цивільний процес. Сімейне право. Трудове право. Міжнародне приватне право. Господарське право. Господарсько-процесуальне право.

As a conclusion, we can say that the CCU is overloaded with standards, these issues should be regulated in special normative legal acts.

The terms on which the parties have reached an agreement form the content of the contract. In legal science, the terms of the contract are referred to as groups: both essential and optional. The essential terms of a rent (lease) are the terms of its object, its validity and the payment for the use of the thing.

Art. 638 of the CCU summarized and determined that the essential terms of the contract are the terms of the subject of the contract, conditions that are defined by law as essential or necessary for the contracts of this type, as well as all those conditions for which at least one of the parties has to be reached by application consent. There are no provisions in the DCFR to summarize the essential conditions.

We believe there is no need to list in the civil act itself the terms of the agreement, - these rules should be contained for convenience in special acts.

An essential element of the agreement is its subject. Art. 760 of CCU determines the subject of an agreement may be a thing which is determined by individual characteristics and which retains its original appearance when reused (non-consumable thing). Property rights may be the subject of the lease agreement [1].

DCFR does not focus on the various objects of leasehold. IV.B. - 1: 101 of this act implies that the goods are the subject [2].

We can say that this is the most acceptable and convenient application of the object of the contract - a single value that eliminates confusion. After all, property, as value, contains a separate thing, a set of things, as well as property rights and obligations.

In the scientific literature, some researchers have noted that the term should not be determined by the essential condition of the lease. However, we cannot agree, and in this regard we point out the possibility of concluding a lease for an indefinite period, due to at least two factors: first, the need to determine the lease term of the agreement is not always justified, because by concluding an agreement, each party pursues a specific purpose that may sometimes depend on subjective or objective circumstances making it impossible rationally determine the term of lease.

Article $763 \mathrm{CCU}$ is determined the lease agreement shall be concluded for the term established by the agreement. If the term of the lease is not set, the lease shall be considered to be concluded for an indefinite period. Each of the parties to the lease agreement, concluded for an indefinite period, can withdraw from the contract at any time, giving written notice to the other party for one month, and in case of renting real estate - for three months. The contract or the law may set another term to prevent the termination of the lease contract for an indefinite period. The law may set the maximum ( $\max$ ) terms of the lease agreement for certain types of property. If, before the expiration of the statutory maximum lease term, neither party has terminated the contract concluded for an indefinite period, it shall terminate with the expiration of the maximum term of the agreement. A lease agreement that exceeds the statutory maximum period is considered to have been concluded for a period corresponding to the maximum term [1].

The term of the rent (lease) not only determines the time period of using the property, but also affects the form of the contract. Thus, according to Art. 793, 794 of the CCU the agreement of the lease of the building for a period of three or more years is subject to a notarial certificate, and the right of use that arises on its basis is state registration [1]. In this case, there may be discussions about the need for a notarization of the lease agreement (lease) concluded for an indefinite period and state registration of rights arising from it. We consider it expedient, since the lease term for such a contract can be three or more years, then they should be concluded according to the requirements of Art. Art. 793, 794 of the Civil Code of Ukraine in a written form and certify by a notary, where the real estate right is subject for registration. Failure to comply with such conditions nullifies such a contract.

Part B Chapter 2 of DCFR is fixed lodge Lease period. It distinguishes the beginning of the lease term where: The lease period starts: (a) at the time determinable from the terms agreed by the parties; (b) if a time frame within which the lease period is to start can be determined, at any time chosen by the lessor within that time frame unless the circumstances of the case indicate that the lessee is to choose the time; (c) in any other case, a reasonable time after the conclusion of the contract, at the request of either party. (2) The lease period starts at the time when the lessee takes control of the goods if this is earlier than the starting time under paragraph (1) [2].

IV.B.-2:102 DCFR: End of lease period (1) A definite lease period ends at the time determinable from the terms agreed by the parties. A definite lease period cannot be terminated unilaterally beforehand by giving notice. (2) An indefinite lease period ends at the time specified in a notice of termination given by either party. (3) A notice under paragraph (2) is effective only if the time specified in the notice of termination is in compliance with the terms agreed by the parties or, if the period of notice cannot be determined from such terms, a reasonable time after the notice has reached the other party [2]. 
Maika N., Butryn-Boka N.

Main provisions of lease agreement: draft common frame of reference and civil code of Ukraine

A positive experience of legal regulation is the absence of a minimum and maximum term.

For the emergence of the contract requires an external expression of will, and is available for the correct perception and understanding of others. The will to enter into a contract can be expressed verbally, in writing, with certain behavior, and in some cases by silence or by concerted action.

In Chapter 58 of CCU there is no provision for determining the general form of the agreement. With regard to the form of certain types of employment contract, the requirement for the form is stated, both verbally and in writing in some cases, notarized agreement itself. Article 828, concerning household items, the employment contract may be concluded orally. With respect to other individually determined things only written (Rent of a vehicle ch. 1 Art. 799 of the CCU, rent real estate - Art. 793 of the CCU) [1]. In some cases, notarization of the agreement itself: the lease agreement for the vehicle with the participation of an individual is a subject for notary's certification; the lease of a building or other capital construction (their separate parts) for a period of three years or more is subject for notary's certification.

The right to lease real estate property, in addition to compliance with the form of the agreement, the transfer of property for use, must also be obligatory to be registered in the State Register of Property Rights in accordance with Article.182 of the CCU [1].

In DCFR, requirements for the form can be either oral or written. Specific requirements for the form of the lease are not specified. It contains a huge amount of registration rules relating to the emergence, change and termination of property rights.

IX.-3:103 DCFR: Security right made effective by several methods: (1) If a security right has been made effective by registration, possession or control, it may be made effective also by any of the other methods. Where the effects diverge, the stronger effects of a chosen method prevail. (2) The preceding rules also apply if a security right that is exempted from the requirements is also made effective by registration, possession or control.

IX.-3:105 DCFR: Security right in an accessory to an immovable A security right in an accessory to an immovable may upon accession also be made effective by registration or annotation in a land register, provided this is authorised by the law governing the land register [2].

Summarizing, we can conclude that legislators of all countries have taken care to ensure property rights arising from the lease.

Conclusions. Therefore, based on the analysis of the private law acts, we can conclude that the DCFR generalized more wistful institute of use of property, and in our opinion, it is more acceptable for ease use in practice. We believe that the legislation should apply the unified terminology of the most important institutions. Also, we can say that the CCU is overloaded with standards, these issues should be regulated in special normative legal acts. That is why the process of recodification is intended to optimize the CCU in accordance with the European principles of private law.

\section{References}

1. Draft Common Frame of Reference. 2009. Retrieved from https://www.law.kuleuven.be/personal/ mstorme/2009_02_DCFR_OutlineEdition.pdf [in English].

2. Civil Code of Ukraine. № 435-IV. 16.01.2003. Retrieved from https://zakon.rada.gov.ua/laws/show/435-15 [in English].

3. Chang-Yuеб Shen, Ling-Yunб Zhang (MSMI 2016). On The Protection of the Lease Contract of the House. $3 r d$ International Conference on Management Science and Management Innovation, 91-93. Retrieved from https://www.atlantis-press.com/proceedings/msmi-16/25861770 [in English].

4. Hamidi, M, Liao, H and Szidarovszky, F. (2016). Non-cooperative and cooperative game-theoretic models for usage-based lease contracts. European Journal of Operational Research, 163-174 [in English].

5. Louis, HG Slangen, Nico, BP Polman (2008). Land lease contracts: properties and the value of bundles of property rights. NJAS-Wageningen Journal of Life Sciences, 397-412 [in English].

Стаття надійшла до редакції 12.02.2020. 